This item was submitted to Loughborough's Research Repository by the author.

Items in Figshare are protected by copyright, with all rights reserved, unless otherwise indicated.

\title{
Overcoming the challenges that hinder new service development by manufacturers with diverse services strategies
}

\section{PLEASE CITE THE PUBLISHED VERSION}

http://dx.doi.org/10.1016/j.jpe.2017.01.013

\section{PUBLISHER}

(C) Elsevier

\section{VERSION}

AM (Accepted Manuscript)

\section{PUBLISHER STATEMENT}

This work is made available according to the conditions of the Creative Commons Attribution-NonCommercialNoDerivatives 4.0 International (CC BY-NC-ND 4.0) licence. Full details of this licence are available at: https://creativecommons.org/licenses/by-nc-nd/4.0/

\section{LICENCE}

CC BY-NC-ND 4.0

\section{REPOSITORY RECORD}

Burton, James O., Victoria Story, Chris Raddats, and Judy Zolkiewski. 2019. "Overcoming the Challenges That Hinder New Service Development by Manufacturers with Diverse Services Strategies”. figshare. https://hdl.handle.net/2134/24300. 
Overcoming the challenges that hinder new service development by manufacturers with diverse services strategies

Jamie Burton $^{\mathrm{a} *}$, Vicky M. Story ${ }^{\mathrm{b}}$, Chris Raddats ${ }^{\mathrm{c}}$, Judy Zolkiewski ${ }^{\mathrm{a}}$

This is a pre-print (non-publisher's document). Please cite the published article:

Burton, J., Story, V.M., Raddats, C., Zolkiewski, J., (forthcoming) Overcoming the challenges that hinder new service development by manufacturers with diverse services strategies, International Journal of Production Economics,

${ }^{a}$ Alliance Manchester Business School, University of Manchester, Booth Street West, Manchester, M15 6PB, UK. E-mail address: Jamie.Burton@manchester.ac.uk; Tel. +44 161 2756508

${ }^{b}$ School of Business and Economics, Loughborough University, Ashby Road, Loughborough, LE11 3TU, UK. E-mail address: V.M.Story@lboro.ac.uk

${ }^{\mathrm{C}}$ University of Liverpool Management School, University of Liverpool, Chatham Street, Liverpool, L69 7ZH, UK. E-mail address: C.Raddats@liverpool.ac.uk.

${ }^{a}$ AllianceManchester Business School, University of Manchester, Booth Street West, Manchester, M15 6PB, UK. E-mail address: Judy.Zolkiewski@manchester.ac.uk

* Corresponding Author

\section{Abstract}


This paper explores the new service development (NSD) challenges that manufacturers face in undertaking servitization initiatives and their attempts to overcome these challenges. Prior work identifies some generic NSD challenges and manufacturers' responses to them. However, understanding how such responses relate to the manufacturer's services strategy remains under-explored. Recent research suggests that manufacturers adopt diverse service strategies and this diversity provides the context for our study. Four case studies are undertaken in large UK-based manufacturers with services strategies differing with respect to the importance of services within their portfolios of offerings. We identify several NSD process challenges facing manufacturers and discuss how the case organisations seek to respond to them. Different degrees of product-logic drive NSD for each of the cases, suggesting manufacturers risk losing key product advantages if they try to 'break free' from their product heritage. However, this can limit the role that services ultimately play in a manufacturing business, potentially putting it at risk from other actors' radical service innovations. Responses to challenges differ depending on the services strategy adopted. The more enthusiastic organisations have to overcome more challenges than those demonstrating lower levels of enthusiasm. The study offers a more nuanced understanding of how manufacturers can overcome key NSD challenges to create new services. Based on the study, seven propositions are presented regarding NSD by manufacturing organisations.

Keywords: Servitization Challenges; New Service Development Processes; Manufacturers' Services Strategies 


\section{Introduction}

Many manufacturers, seeking opportunities for value creation in the face of falling product revenues and increasingly competitive product markets, are developing new service offerings to complement, or take the place of, product offerings (Baines \& Lightfoot, 2014). This process is termed servitization (Vandermerwe \& Rada, 1989) or service infusion (Brax, 2005), and involves servitizing manufacturers supplementing products with services (Oliva \& Kallenberg, 2003). Extant literature (e.g., Mathieu, 2001a) generally describes servitization as an organisational transformation process from a manufacturer largely focused on products and Services Supporting Products (SSPs) to a provider of Services Supporting the Clients' actions (SSCs), similar to the concept of 'advanced services' (Baines \& Lightfoot, 2014).

Despite perceived benefits of servitization, evidence relating to successful performance outcomes is by no means clear (Baveja, Gilbert \& Ledingham, 2004; Suarez, Cusumano \& Kahl, 2013), often due to the various challenges manufacturers face. One notable challenge is developing new services, which is critical for building competitive advantage (Ostrom, Bitner, Brown, Burkhard, Goul, Smith-Daniels, Demirkan \& Rabinovich, 2010). A manufacturer's new service offerings tend to align to its service strategy (Gremyr, Witell, Löfberg, Edvardsson \& Fundin, 2014; Lightfoot \& Gebauer, 2011). However, recent recognition that manufacturers follow different trajectories and, therefore, have different strategies (Kowalkowski, Windahl, Kindström \& Gebauer, 2015; Peillon, Pellegrin \& Burlat, 2015), suggests that how they overcome the specific challenges they might experience related to new service development (NSD) may also differ. 
Knowledge of manufacturers' NSD activities is still limited (Carlborg, Kindström \& Kowalkowski, 2014; Kindström \& Kowalkowski, 2014). Research has explored manufacturers' generic NSD processes (Ettlie \& Rosenthal, 2011; Gremyr, Löfberg \& Witell, 2010; Kindström \& Kowalkowski, 2009) and the interplay between service and product innovation (Eggert, Thiesbrummel \& Deutscher, 2015; Gremyr et al., 2014; Visnjic, Wiengarten \& Neely, 2016). However, little research to date has considered how NSD processes align to manufacturers' services strategies. Although Lightfoot \& Gebauer (2011) purport to do this, their work builds on Gebauer's (2008) service typology, with service 'strategies' (e.g., after-sales service provider [ASPs]) conceptualised as categories of service offerings (e.g., ASPs offer after-sales services) and neglects services strategies that involve multiple categories of service offerings. Thus, we contend that this issue requires further investigation.

Given that manufacturers adopt a range of services strategies (Löfberg, Witell \& Gustafsson 2010), it is important to develop a more fine-grained understanding of their various NSD efforts. This should enable a better understanding of how manufacturers can develop new service offerings to improve performance outcomes. Thus, the aim of this study is to explore the challenges manufacturers with differing services strategies face in developing new services, and how they respond to them. Two main research questions are subsequently identified:

RQ1) How do new service development process challenges manifest for manufacturers with differing services strategies? 
RQ2) How do manufacturers respond to these challenges?

In the following sections, we set out the theoretical background and research gap, methodology and findings from the study. Thereafter, the study provides three main contributions. First, it provides additional support to the emerging view that manufacturers can adopt different hybrid approaches that support their combined product and services

offering' strategy). Second, this research goes beyond the macro exploration of the general challenges hindering manufacturers' servitization efforts, and instead considers the specific issues manufacturers with differing services strategies face in relation to the typical NSD process challenges. Third, while some generic insight has previously been offered on how to overcome servitization challenges, this research identifies specific responses to the NSD challenges based on the services strategies adopted, and offers propositions for further research.

\section{Literature Review}

\subsection{Manufacturers' services strategies}

Many manufacturers are striving to transition to more service-focused strategies (Fang, Palmatier \& Steenkamp, 2008), yet limited empirical attention has been given to what adopting these might entail. Most discussion comprises high-level description of services strategies (e.g. Oliva \& Kallenberg, 2003; Fang et al., 2008) or implicitly assumes strategic decisions related to implementing new service offerings will be easy for manufacturers to 
execute. Such strategic conundrums may result in service paradoxes (Brax, 2005; Neely, 2008) and servitization failures (Benedettini, Neely \& Swink, 2015).

Mathieu (2001b) argues that there is a need to move beyond strategies that relate simply to service offerings, conceptualising service specificity and organisational intensity (how the services impact on the firm) as key dimensions. However, consensus about the factors that drive these services strategies has not been reached, with Löfberg Witell \& Gustafsson (2010) identifying resource availability and position in the supply chain as key, while Gebauer, Paiola \& Edvardsson (2010) argue that value chain position and business environment are the driving factors of service strategy. Despite the importance of a manufacturer's specific services strategy to its servitization efforts, it is perhaps surprising that only two services strategy typologies have been developed (i.e., Gebauer, 2008; Raddats \& Kowalkowski, 2014), which use large samples covering a range of sectors, suggesting that they have applicability to a wide cross-section of manufacturers.

Gebauer (2008) identifies four groupings of manufacturers that follow different services strategies: after-sales service providers (ASPs), customer support providers (CSPs), outsourcing partners (OPs) and development partners (DPs). These 'strategies' appear to equate to categories of service offerings (e.g., OPs offer operational services), in that they do not address strategies that include multiple categories of service offerings. Thus, Gebauer's (2008) typology appears simplistic in that it contains only one category of service offering in each services strategy, and is, therefore, similar to service offering typologies proposed by Tukker (2004) and Baines \& Lightfoot (2014). 
Although it could be questioned whether Raddats \& Kowalkowski (2014) present a true strategy typology, it does offer a typology of strategies that caters for multiple categories of service offerings; seen as necessary to deal with diverse customer needs (Rabetino, Kohtamäki, Lehtonen \& Kostama, 2015). Raddats \& Kowalkowski (2014) identify three clusters of firms: 'doubters' (view services as a weak differentiating factor and consequently offer very few services); 'pragmatists' (view services as an approach to creating greater product differentiation and primarily provide SSPs for their own products); 'enthusiasts' (view services as a key growth strategy and offer SSPs and SSCs for their own and other vendors' products). These clusters appear to be indicative of the underlying strategic approaches to the development of service offering portfolios by these firms, suggesting that a deeper, more nuanced, understanding of these different services strategies, and how they affect NSD, is needed.

\subsection{New service development in a manufacturing setting}

Key to successful servitization is the ability to develop new services/service innovation. In this paper we align to the mainstream view that service innovation is the outcome of NSD efforts (Snyder, Witell, Gustafsson, Fombelle \& Kristensson, 2016). Within manufacturers it is likely that service innovation will be different to that in traditional service industries (Baines, Lightfoot, Benedettini \& Kay, 2009; Kowalkowski, Kindström, Alejandro, Brege \& Biggemann, 2012; Lightfoot \& Gebauer, 2011); primarily because services may be part of hybrid product and service offerings (Ulaga \& Reinartz, 2011) or may compete with products for limited resources for innovation within the same firm (Eggert et al. 2015). 
In keeping with de Jong and Vermeulen (2003), we view NSD efforts as not just pertaining to the uniqueness of a new offering, but also encompassing the delivery system, the technology or operational processes used and the customer interface. Thus, for servitizing manufacturers, new product and service development are likely to be closely inter-related (Gallouj \& Windrum, 2009; Gremyr et al., 2014; Raja, Bourne, Goffin, Çakkol \& Martinez, 2013), with both important for success (Eggert et al., 2015; Ostrom et al., 2010; Visnjic et al., 2016). Taking a holistic view of NSD efforts is important when considering a manufacturing context, wherein service development is inexorably linked to product development and service delivery, because these interrelationships have the potential to create tensions and require changes to structures, processes and resources (Baines et al., 2009; Gebauer, Edvardsson, Gustafsson \& Witell, 2010).

A key strategic decision for manufacturers is whether to introduce new services designed to broaden the range of offerings (SSPs) or replace product offerings (SSCs) (Kindström \& Kowalkowski, 2014). For SSPs, Lightfoot \& Gebauer (2011) found that manufacturers place less emphasis on design, test and launch phases than those offering SSCs. For SSCs, Gremyr et al., (2014) found that NSD processes are more structured and need to address the role of the customer in the process; simply adjusting NPD processes is not seen as viable, given the fundamentally different nature of service offerings (Gremyr et al., 2010). New or revised procedures and processes are, therefore, required (Ettlie \& Rosenthal, 2011; Kindström \& Kowalkowski, 2009; Santamaría, Jesús Nieto \& Miles, 2012). It is likely that such decisions will be affected by the strategic approach of the servitizing manufacturers with respect to the portfolios of services offered. Indeed Neu \& Brown (2005) discuss how firms that successfully servitize have to adapt organisational factors, including structure and 
strategising processes. Hence, a more nuanced understanding of how NSD processes are adapted would provide deeper insights on servitization efforts.

\subsection{Manufacturer NSD challenges and responses}

Manufacturers must adopt more service-related processes in order to develop new services (Kindström \& Kowalkowski, 2009). While this issue is applicable, to some extent, for all manufacturers, it appears most applicable for enthusiasts, who are more likely to offer advanced services to their customers. However, manufacturers may face issues in reconciling radical service innovations into a product-focused process (Gremyr et al., 2014). To address this challenge, manufacturers may need a more customer-focused perspective; a proper understanding of customer value (Bettencourt \& Brown, 2013), be able to collaborate with customers (Santamarìa et al., 2012) and to foster 'innovation champions' to manage introduction of new services (Ettlie \& Rosenthal, 2012).

Previous work aligns NSD/services innovation with categories of services offerings (SSPs and SSCs) (e.g., Eggert, Hogreve, Ulaga \& Muenkhoff, 2011) or looks at this from a capabilities perspective (e.g., Kindstrom, Kowalkowski \& Sandberg, 2013). However, it does not consider the services strategies of manufacturers; with respect to how they might impact the NSD practices and responses to challenges faced. It can be contended that enthusiasts are likely to require different NSD practices to pragmatists for whom services are more focused on existing products. Also, no research to date has addressed the NSD rationale of doubters, in terms of the barriers they perceive to developing new services and the implications for their NSD activities. Understanding differences in the impact of the challenges for manufacturers 
with different services strategies and responses should help us to understand the reasons for varying degrees of success of manufacturers' NSD efforts.

While literature identifies individual servitization challenges and responses for manufacturers adopting different service strategies in isolation (Gebauer, 2008; Turunen \& Finne, 2014, Ostrom et al, 2010, Nijssen, Hillebrand, Vermeulen \& Kemp, 2006), in this paper we focus on the challenges related to developing new services-related processes for a range of manufacturers with differing services strategies. These NSD challenges are relevant to manufacturers with heterogeneous strategies and the variation in responses to these challenges have not been considered in the literature.

\section{Methodology}

\subsection{Research strategy}

The nature of the study required a qualitative research methodology; advisable when there is incomplete understanding of a particular phenomenon (Miles \& Huberman, 1994). A case study method (Yin, 2013) is appropriate when exploring NSD processes, since it facilitates an understanding of the emergence of these processes (Aaboen, Dubois \& Lind, 2012).

\subsection{Case selection}

Eisenhardt (1989) argues that theoretical sampling is key to building theory from case studies; that case selection should be driven by the need to ensure that theory can replicated or extended. This strategy is adopted extensively in case research, e.g. Neu \& Brown (2005), Wilson \& Vlosky (1997). We purposively selected case organisations from our population of interest (Eisenhardt, 1989) (large global manufacturers capable of performing 
servitization in similar ways) specifically in anticipation that they may demonstrate variation in their approach to NSD based on their services strategies. Given the commonality of NPD practices across manufacturing firms (with the adoption or adaptation of Cooper's stagegate $^{\mathrm{TM}}$ model - Cooper \& Edgett [2012]) and the fact that NSD is closely linked to New Product Development (NPD) in manufacturers (Kindstrom \& Kowalkowski, 2009), selecting cases from different sectors should provide greater richness to the findings.

Raddats \& Kowalkowski's (2014) services strategy typology was adopted to purposively identify B2B manufacturers with different services strategies in order to apply theoretical replication logic ensuring external validity (Yin, 2013) with respect to the processes being explored. To apply theoretical replication, two enthusiasts (AeroCo; TelCo) were selected from sectors supplying complex, highly customised products (aerospace and telecommunications), as manufacturers in these sectors are generally the most servitized (Dachs, Biege, Borowiecki, Lay, Jäger \& Schartinger, 2014). A pragmatist (ChemCo) was selected from a sector with less complex and customised products (chemicals), as manufacturers in these sectors are less servitized (Dachs et al., 2014). A doubter (SecurCo) was selected from the security sector. Although manufacturers in this sector provide complex, highly customised products, they typically provide few services; the industry structure means that manufacturers generally use distributors, which provide most of the services to customers.

The selected manufacturers were multi-nationals with a significant UK presence, possessing a heritage and track record of technological innovation. In order to establish construct validity (Yin, 2013), the organisations were located on the Raddats \& Kowalkowski (2014) 
services strategy typology through a triangulating review (Creswell, 2003) of documentary evidence, (including websites, archival records) and preliminary interviews. Two enthusiasts were included because this is a relatively large group (within Raddats \& Kowalkowski's [2014] sample). Initial data suggested that the enthusiast category might need further refinement as we predicted greater variance in their service offerings.

\subsection{Data collection}

Data were collected from documentary sources and via 24 in-depth interviews with senior marketing and service operations managers responsible for their organisations' services; a minimum of four per company, with more respondents from more servitized organisations to deliver greater construct validity (Yin, 2013) (see Table 1). 
Table 1: Companies and individuals that took part in the study

\begin{tabular}{|c|c|c|c|c|c|}
\hline Manufacturer & $\begin{array}{l}\text { Ownership } \\
\text { of parent } \\
\text { company }\end{array}$ & $\begin{array}{l}\text { Sector (products/ } \\
\text { applications) }\end{array}$ & Typical services & $\begin{array}{l}\text { Classification (evidence supporting } \\
\text { classification) }\end{array}$ & $\begin{array}{l}\text { Number of } \\
\text { interviewees } \\
\text { (functional areas) }\end{array}$ \\
\hline AeroCo & European & $\begin{array}{l}\text { Aerospace (avionics } \\
\text { for military and } \\
\text { commercial } \\
\text { applications) }\end{array}$ & $\begin{array}{l}\text { From spares and } \\
\text { repairs through to } \\
\text { availability and } \\
\text { capability } \\
\text { contracting }\end{array}$ & $\begin{array}{l}\text { Enthusiast (services }>25 \% \text { overall } \\
\text { revenue and heavily emphasised in } \\
\text { promoting customer offerings) }\end{array}$ & $\begin{array}{l}8 \text { ( } 2 \text { - marketing; } \\
6 \text { - service } \\
\text { operations) }\end{array}$ \\
\hline SecurCo & American & $\begin{array}{l}\text { Security (alarm } \\
\text { systems for corporate } \\
\text { customers) }\end{array}$ & $\begin{array}{l}\text { Limited range of } \\
\text { technical support } \\
\text { service offerings }\end{array}$ & $\begin{array}{l}\text { Doubter (services }<5 \% \text { overall revenue } \\
\text { and not emphasised in promoting } \\
\text { customer offerings) }\end{array}$ & $\begin{array}{l}4 \text { ( } 3 \text { - marketing; } \\
1 \text { - service } \\
\text { operations) }\end{array}$ \\
\hline
\end{tabular}




\subsection{Data analysis}

In line with our research aim, the unit of analysis for the study was the manufacturer services strategy (enthusiast, pragmatist, doubter). Using this unit of analysis enables a cross-case comparison to be made of NSD process challenges/responses aligned to different strategies. Starting with a priori coding categories from literature, thematic analysis was undertaken (Dubois \& Gadde, 2002). Where passages or strings of texts contained multiple themes, they were categorised within multiple parallel codes (King, 2004). A singular tabular display was developed that facilitated within-case analysis, cross-case pattern matching (Eisenhardt, 1989) and explanation building (Yin, 2013), mostly in terms of consistent patterns between the two enthusiasts (and sometimes the pragmatist), being compared with contrasting data from the doubter.

The development of an initial set of themes from the literature facilitated the application of a pattern matching logic in order to check internal validity, via the comparison of findings with previously identified phenomena (Yin, 2013). Additional 'new' sub-categories also arose from the data (Eisenhardt, 1989; King, 2004). The first six transcripts (selected from across the cases) were thematically coded independently by two of the authors, using template analysis. The full research team then met to review and agree the initial template (King, 2004). The remaining transcripts were subsequently coded and the final NSD themes (see Appendix) emerged, through an interpretive process (Hirschman, 1986) of reading and reviewing of the content. Thematic saturation was deemed to have been achieved when no new themes emerged for a particular case (Silverman \& Marvasti, 2008) and a final coding structure achieved (and checked by joint team review) once this point was reached for all 
four cases (King, 2004). Thus, we claim credibility of the inferences developed in the interpretation of the cases we present, through the use of documented peer review and reflection of our coding (Creswell \& Miller, 2000; Hirschman, 1986), contributing to the reliability of the study (Yin, 2013). External validity was ensured through the review of previous literature and use of replication logic (Yin, 2013).

\section{Findings and Discussion}

Table 2, below, sets out a cross-case summary of the significance of challenges, and extent or absence of, responses relating to developing NSD processes; data in the appendix, illustrates the key themes linked to the challenges and responses identified by the four organisations, relating to NSD processes. 
Table 2: Cross case comparison: Developing NSD Processes

\begin{tabular}{|c|c|c|c|c|}
\hline Theme & $\begin{array}{l}\text { SecurCo (doubter/constrained) } \\
\text { Disconnected processes }\end{array}$ & $\begin{array}{l}\text { ChemCo (pragmatist) } \\
\text { Developing processes }\end{array}$ & $\begin{array}{l}\text { TelCo (restrained-enthusiast) } \\
\text { Developing global processes }\end{array}$ & $\begin{array}{l}\text { AeroCo (enthusiast) } \\
\text { Effective processes }\end{array}$ \\
\hline $\begin{array}{l}\text { Product vs. } \\
\text { Services } \\
\text { innovation } \\
\text { mind-set }\end{array}$ & $\begin{array}{l}\text { Competitors' service offerings } \\
\text { perceived as gimmicks, product } \\
\text { logic dominant }\end{array}$ & $\begin{array}{l}\text { Service-minded but } \\
\text { business still product } \\
\text { focussed }\end{array}$ & $\begin{array}{l}\text { Services are product attached } \\
\text { (initial heterogeneity of } \\
\text { services caused profitability } \\
\text { issues) }\end{array}$ & $\begin{array}{l}\text { Maintain both product-led } \\
\text { and service-led approaches }\end{array}$ \\
\hline $\begin{array}{l}\text { NPD/NSD } \\
\text { processes }\end{array}$ & $\begin{array}{l}\text { Inexperienced service innovator: } \\
\text { Well-defined but traditional NSD } \\
\text { \& NPD processes; not customer- } \\
\text { driven }\end{array}$ & $\begin{array}{l}\text { Experienced } \\
\text { innovator: Creative, } \\
\text { problem solving } \\
\text { approach, less } \\
\text { formalised }\end{array}$ & $\begin{array}{l}\text { Experienced innovator: Stage- } \\
\text { gate process for NPD \& NSD, } \\
\text { NSD practices highly } \\
\text { developed but cautious over } \\
\text { which services progress } \\
\text { through }\end{array}$ & $\begin{array}{l}\text { Experienced innovator: } \\
\text { Stage-gate process for NPD } \\
\text { \& NSD, encourages } \\
\text { responsiveness to customer } \\
\text { problems }\end{array}$ \\
\hline $\begin{array}{l}\text { Connections } \\
\text { between NPD } \\
\text { and NSD }\end{array}$ & $\begin{array}{l}\text { Limited connections between } \\
\text { NPD and NSD staff }\end{array}$ & $\begin{array}{l}\text { One-way } \\
\text { communication (sales } \\
\text { feedback to product } \\
\text { people) }\end{array}$ & $\begin{array}{l}\text { Key touch-points between } \\
\text { NSD \& NPD, two-way balanced } \\
\text { communication (product } \\
\text { people understand services) }\end{array}$ & $\begin{array}{l}\text { Key touch-points between } \\
\text { NSD \& NPD, two-way } \\
\text { unbalanced communications } \\
\text { (product people dominate } \\
\text { interactions) }\end{array}$ \\
\hline
\end{tabular}




\subsection{Product versus services innovation mind-set}

Innovation strategy is a key aspect of NPD/NSD activities, and, as identified by Lightfoot \& Gebauer, 2011, the servitizing firm's mind-set appears to be central to this. Both SecurCo and ChemCo are product-led; believing the purpose of services is to sell their products. SecurCo lacks capabilities to link complex services to their products. ChemCo has these capabilities but are wary of becoming too service focused (Kowalkowski et al., 2015), which they link to a productivity risk (Öhman, Finne \& Holmström, 2015). They adopt a services-led strategy; but with a very strong focus on their own products, to avoid the 'tail wagging the dog'.

This contrasts with TelCo, who initially adopted a very services-led strategy, but pulled back because of profitability problems linked to services heterogeneity. TelCo overcame the product mind-set inertia problem relatively easily. However, this quick move to a new service mind-set meant that staff were given relatively free reign to develop services; leading to excessive services proliferation, creating confusion and causing financial losses through excessive value transfer to customers. Following retrenchment efforts, TelCo pulled back from a 'fully' advanced services trajectory and re-focused on delivering a reduced 'menu' of profitable product-attached services (SSPs). This approach is similar, but distinct, from ChemCo's product-led approach because, product and services sales are equally important. In retrenching, TelCo has modularised service offerings into packages to control costs; creating a more profitable service business, with recognition that 'service-led' sales in a product-attached mode can deliver greater value by providing 'pull through' product demand. 
AeroCo attempted to build a services mind-set with a bias towards their own products, but with recognition that, if their products hinder growth, they can look outside the organisation for solutions. AeroCo appear to maintain both a product- and service-led approach and have ended up with significant services growth.

What is clear from these examples is that all manufacturers, even the enthusiasts, need to maintain some focus on their core activities; essentially to take a balanced approach to their strategic focus, rather than being either too product-led or too services-led, which can lead to 'service overshoot'. Furthermore, the success of the approach appears to be affected by a firm's ability to modularise their services and the variety of services required by customers. Notwithstanding the argument that servitization is not necessarily a journey from products to services for all firms, it is clear from the cases examined that, in line with prior work (e.g. Fang et al., [2008]), performance is expected to improve for firms adopting more servitized services strategies, as these strategies enable the firm to gain market share and revenue, and build economies of scale and scope, but only up to an optimum point, after which performance may erode, due to such issues as operational complexity and services heterogeneity. Thus, Proposition 1 emerges:

$\mathrm{P} 1:$ The relationship between a firm's innovation mind-set and servitization performance is likely to be an inverted $U$ shape, and likely to be moderated by the level of services heterogeneity, organisational learning capabilities and the potential to modularise.

\subsection{NPD/NSD Processes}


Developing effective NSD processes is a key challenge outlined in extant literature (e.g., Matthyssens \& Vandenbempt, 2008). Interestingly, all four firms utilise pre-existing NPD processes for NSD rather than developing specific NSD processes, which appears to contradict extant NSD research (e.g. Ettlie \& Rosenthal, 2011; de Jong \& Vermeulen, 2003) that services require different NSD processes. TelCo and AeroCo, as experienced innovators, have clear, detailed stage-gate processes used for both products and services, incorporating different processes for different complexities of products/services, with different approval processes, in line with Cooper's (2008) 'lite', 'express' and 'full' processes. However, TelCo, while noting that it can easily cope with different innovation types, recognises the importance of the 'middle' ground for creating services that are differentiated but also standardised and thus restricts which new services are progressed. Of the two Enthusiasts, TelCo has the most developed NSD practices, with services constructed in terms of which elements are provided centrally, regionally or globally; the global role is critical because it drives cost efficiencies through standardisation.

Another key innovation issue relates to progressing good ideas through the process. While stage-gate processes are well-recognised as fundamental to successful innovation, they have some issues related to application; e.g., balancing the strength of the gates (Cooper, 2008). ChemCo, with its more informal process, has no issues with progressing projects. AeroCo seems to have a good balance between creativity and gate reviews, allowing staff creative space to work on important ideas that facilitate responsiveness to customer problems, until they create a plausible case for review; in a sense these can be seen as 'customer champions'. SecurCo appears to have lots of great 'value-add' ideas, often raised by customers, but fails to progress them. Interestingly, ChemCo appears the most customer- 
focused organisation out of our four cases, having a culture of innovating with customers, potentially because of the specialist nature of its products and services. Telco highlights some problems with controls that were put in place as part of the strategic consolidation process, with the innovation pipeline stifled by gate approval limits. However, in line with AeroCo, once TelCo had consolidated the new product-attached strategy, these limits were relaxed to improve prospects of developing more innovative services. Both TelCo and AeroCo ensure managers on gate committees understand services as this appears key to enabling services growth. All the evidence points to better NSD outcomes stemming from firms having formal, but flexible and/or creative, processes driven by strategy and involving a cross-functional team. SecurCo are too restrictive, Telco created too many restrictions, realised that these were hindering growth, and are now building flexibility back in to their NSD process, whereas ChemCo and AeroCo describe their processes as flexible/adaptable. Thus, we propose:

P2: Across all services strategies, developing specialised NSD processes does not improve NSD success over the adoption of more traditional NPD stage-gate processes.

P3: NPD and NSD efforts are more effective when gate review members have services knowledge and when there is greater flexibility/creativity allowed but these effects are more pronounced for more servitized services strategies.

P4: Across all services strategies customer champions representing the voice of the customer improve NSD success but the effect is more pronounced when services are more specialised.

\subsection{Connections between NPD and NSD}


None of the organisations have different services and product development processes, nor do the firms specifically develop products and services in a single process. Instead, the data evidence the importance of having good connectivity between NPD and NSD; discussing key 'touchpoints' between the processes. However, the data also highlight differing levels of inter-connectivity between NPD and NSD processes across the cases. TelCo has the closest processes with multiple, interactive touch points; all products have a 'design for services' programme including both mandatory and optional services, which fits its product-attached mind-set. Furthermore, at TelCo and AeroCo, interaction touchpoints are supported by having 'product' people who understand services and implementation is supported by having good touchpoints between the centre and local service teams. Thus, developing mutual understanding of products and services and good communication flows within the NPD/NSD teams are needed to ensure services progress from idea to deployment.

While touch points exist in all cases, differences exist in the information flows between NPD and NSD touchpoints (either one- or two-way). TelCo data suggest that the flow of information is two-way, with significant evidence of feedback mechanisms in terms of services people feeding into product innovation planning efforts and product people asking about services that might go with new products they are developing. AeroCo also discusses two-way interactions, but highlights power issues - with more coming from the product people to services; based on having longstanding product road-maps, investment programmes and global reputations. Indeed, while AeroCo has developed similar touchpoints between its product and services development teams, evidence does not suggest the processes are 'close' or that teams work collaboratively. Even when information is passing both ways, there can be some key hold-ups in process due to different product 
and services development timescales. In contrast, at ChemCo most communication tends to be one-way; from salespeople to product personnel, but its matrix structure appears to mitigate against internal conflict relating to product-services tensions. SecurCo demonstrates limited evidence of links between NPD and NSD; while they are only producing a few services it is possibly too early in its servitization journey for this to be necessary.

Early in the NSD process, both AeroCo and TelCo engage with customers to better understand their needs and deliver 'smart' customer solutions. At AeroCo, this can involve embedding staff within customers for at least two years; while TelCo typically adopts a consultative selling approach. TelCo specifically describes cultivating relationships with customers to facilitate trials, and benefits from having sister businesses in which they can try out and learn from new innovations. This confirms the benefits of taking a collaborative, customer-centric approach (Bettencourt \& Brown, 2013; Santamaria et al., 2013).

Thus:

P5: Established touchpoints, with three-way communication between sales teams, innovation teams and customers, create better: (i) sharing of customer insight and (ii) learning between NPD and NSD, but the effect is more pronounced for more servitized services strategies when level of interconnectivity between NPD and NSD is higher and balanced (not product- or services-led).

\subsection{People and Services Deployment}


All firms, regardless of services strategy, appear to suffer from a key difficulty related to the deployment of new services, given that most of the services they are developing are 'person' heavy, involving 'highly skilled' people, meaning that organisations cannot grow overnight. This lack of services personnel appears the biggest barrier for SecurCo, causes some issues for ChemCo but has been a big area of investment for both Enthusiasts. However, interestingly, the digital services SecurCo could develop have the potential to reduce services personnel numbers; thus, technology may increasingly offer an alternative resolution to this barrier, as opposed to direct investment in services personnel.

ChemCo highlights a staffing problem related to training existing product-focused staff to develop necessary services capabilities. This was not a unique problem, but was robustly identified at ChemCo (the pragmatist) because it was attempting to deliver services from within its existing structure, without developing a separate service SBU. In contrast, TelCo and AeroCo had distinct services units, with well-trained, service-focused staff.

A second key issue for growing services relates to building service deployment capacity. Both ChemCo and TelCo highlight a need to maintain balanced strategic planning between NSD efforts and the delivery of current offers (the typical explore/exploit dilemma [O'Reilly \& Tushman, 2011]) and to balance resources between products and services. TelCo's consolidation process caused problems; it let some very qualified consultants leave due to perceived over-capacity, who they now need to provide new services because of market growth. Similarly, SecurCo is not prepared to have expensive services experts 'underoccupied'. Its lack of progress, might relate to its lack of prior services capabilities and efficiency concerns. ChemCo overcame this issue by multi-skilling people, working with 
partners to develop global reach, and being happy to service third-party products, using spare personnel capacity. ChemCo's strategic board level commitment to grow services, translates into commitment to scaling the services business and growing market coverage; building a sustainable business model through scale. A key constraint is the scale of capital investment and the 'lack the manpower' required to 'gear up' in every location, because of transportation and legislative issues. In line with Möller \& Rajala's (2007) network approach; ChemCo have partly overcome this issue by using third-party providers, branded with their company logo.

TelCo has tried various approaches to managing this issue around efficient scalability but now has a structure around distinct services lines, a global services delivery centre and regional staff supporting the regional sales teams. It is also focused on trying to modularise services delivery into simplified, remotely delivered components that can be outsourced to sub-contractors. Similarly, AeroCo has a modular menu of solutions and then uses a mixture of onsite specialists and support helpdesks. AeroCo is also beginning to develop simulation tools to support scalability; for example, reducing requirements for 'live training', which lowers costs and training days required. Finally, AeroCo highlights the importance of being prepared to lose money initially, knowing that it can then 'lean' the deployment process via continuous improvements to make it cost effective. This means taking a long-term approach to the commitment of resources to the customer, knowing that longer-term profit will come through 'lean' skills and customer satisfaction.

Based on the differences observed in the approaches identified from the four cases, and recognising the potential of process tools that support scalability and efforts to adapt and 
modularise production capacity and the value of staff and how they are trained, leads to the development of Propositions 6 and 7:

P6: Staff training and support to develop services delivery capabilities are more important when organisations are attempting to deliver services with existing product-focused personnel.

P7: Firms are more likely to overcome the issue of scalability, necessary to become more servitized, if they place greater efforts on: (i) modularisation; (ii) productising service innovations; (iii) flexible people and resource deployment; and, (iv) continuous improvement efforts.

\subsection{Discussion}

This study has identified homogeneity in the NSD challenges faced by the case organisations but heterogeneity in the responses they adopt with evidence of variation depending on their services strategy. The responses to the NSD challenges tend to be a mixture of cultural, structural, people and process changes. Four themes were identified that illustrate these issues.

In terms of innovation mind-set, all four organisations retain varying degrees of productfocus, based on their perceptions of strong product competitive advantages that their products provide. This retained product-focused innovation mind-set means that in all cases NPD and NSD processes are not separate, but rather are closely related to each other (Gallouj \& Windrum, 2009; Gremyr et al., 2014). SecurCo demonstrates a mind-set that is probably common among doubters, namely that services are seen as peripheral to its 
business and new services are too complicated or problematic to develop. ChemCo has built a nascent services business based on adding complex service offerings to its non-complex products (Dachs et al., 2014). The restrained-enthusiast, TelCo, had to rein back services volumes after overshooting, and has retrenched in terms of focusing more on new services that support products, thus returning to more of a product innovation mind-set. AeroCo, meanwhile, remains product-led in traditional aerospace markets but less so in nontraditional markets where it has a stronger service innovation mind-set; it currently lacks a strong suite of products to address these markets. Thus, our findings add to existing research which sets out multiple service trajectories (Kowalkowski et al., 2015) but demonstrates that a stronger service innovation mind-set is easier to develop when there is not the need to support existing products.

With respect to NPD/NSD processes, all cases demonstrate the use of discrete NSD processes; although they are still linked to existing NPD processes (Kindstrom \& Kowalkowski, 2009). Our findings, however, suggest the need for separate processes (Santamaría et al., 2012; Gremyr et al., 2014) might be overstated, with even enthusiasts adapting existing NPD processes. Within all four organisations, NPD processes are well established and there seems a desire to have a commonality of approach for all new offerings, be they products or services, to ensure a consistent approach and comparability in assessing the merits of new offerings. Interestingly, organisations with more formal NSD processes indicated they would be challenged by genuinely radical innovations (supporting Gremyr et al., 2014). 
NSD processes involved significant interactions with customers (Bettencourt \& Brown, 2013;

Ettlie \& Rosenthal, 2011). All but the doubter appear to be proactive with regards to obtaining customer insights and getting customers involved in the development process, showing the benefits of 'customer champions' over 'traditional innovation champions' that champion the innovation rather than the customer voice (cf. Ettlie \& Rosenthal, 2012). This customer focus contrasts with the view in the literature that few manufacturers have the knowledge and capability to effectively engage the customer in the NSD process (Santamaría et al., 2012). However, there are clear differences in how these insights are generated. For example, the enthusiast embeds staff within customer organisations, an effective but resource-expensive approach to understanding customer value (Bettencourt \& Brown, 2013). The restrained-enthusiast, on the other hand, appears to focus resources on cultivating specific customer relationships that they feel will support the trial of key new services, thus taking more of a customer collaboration approach (Santamaría et al., 2012).

In terms of the connections between NPD and NSD processes, although our study supports previous research in finding that NPD and NSD are closely inter-related (Gallouj \& Windrum, 2009; Gremyr et al., 2014; Raja et al., 2013), it provides a more nuanced understanding of this issue. In particular, the enthusiasts have developed key touchpoints between the processes to ensure that new services support new products and vice versa. That said, both enthusiasts face some problems managing the interactions between product and services specialist staff. TelCo appears to demonstrate better two-way communications between services and product staff. This is perhaps due to their technology focus, evidencing multiple, balanced interactive touchpoints between their NPD and NSD processes. AeroCo also has two-way communications but the balance appears to be more products-to-services, 
with some evidence of problems with regards to interactive communications. By comparison, ChemCo's communications are more services to products, via the sales team. Our cases support the extant literature in that addressing NSD during initial phases of NPD helps manufacturers build successful product and service offerings, as long as the weaknesses of relying on existing product-based routines can be managed (Ulaga \& Reinartz 2011; Gremyr et al. 2014).

With respect to people and services deployment, a key challenge identified across all cases was the need for people with the right service skillset to develop services (Raddats, Burton \& Ashman, 2015). Indeed, this challenge reflects a wider problem, in that a manufacturer's product-driven capabilities are unlikely to be sufficient for service innovation (Kindström et al., 2013;). For example, SecurCo lacked the necessary services personnel and processes (de Jong \& Vermeulen, 2003) and, therefore, felt unable to develop new services. ChemCo faced constraints in terms of scaling new services through lack of requisite capabilities to deliver them in all markets. AeroCo and TelCo demonstrated the most long-term commitment to NSD activities, accepting that this involved taking on investment risks when tackling this challenge. Evidence suggests that manufacturers directing their innovation efforts to both products and services outperform peers that do not (Eggert et al., 2015); although the risk for an overly product-focused organisation is that when funding is limited product innovation will be prioritised over service innovation.

Finally, our study also suggests that the services strategies categories outlined in Raddats \& Kowalkowski (2014) needs further refinement. The data from the two enthusiast cases highlight differences between TelCo and AeroCo in a number of areas that lead us to 
speculate that future research needs to consider four types of services strategies; with enthusiasts broken down into restrained-enthusiasts and enthusiasts. Additionally, we note that the 'doubter' may be in this position because of constraints resulting from industry structure and its reliance on its network of distributors to provide services.

\section{Conclusions}

This research goes beyond the macro exploration of the general challenges hindering manufacturers' servitization efforts, and instead considers the specific challenges to NSD for manufacturers with differing services strategies. In this study, we have identified and explored how the challenges they faced affect their new services development efforts (RQ1), whether the responses they implement to overcome these challenges vary according to these differing services strategies adopted (RQ2) and specifically we compare the variation in the types of challenges and responses relating to NSD processes. In developing research propositions through a cross-case explanation of our research questions we have been able to offer a number of theoretical contributions.

First, we identify various degrees of product-logic that drive NSD for manufacturers, even those that are service enthusiasts. Thus, these findings counter previous widely accepted views of servitization as a transformation process to a purely service-focused strategy (Mathieu, 2001b; Oliva \& Kallenberg, 2003), supporting an alternative emerging view that manufacturers can adopt different hybrid approaches that supports their combined product and services offering' strategy (Kowalkowski et al., 2015; Peillon et al., 2015; Ulaga \& Reinartz, 2011). Additionally, they suggest that the services strategies identified by Raddats \& 
Kowalkowski (2014) need refining by further dividing the enthusiast to reflect the prevalence of internal organisational constraints that differentiate between firms adopting a more restrained version of the enthusiast services strategy. We suggest also that further research is needed to identify if the doubter category requires subdivision to account for external industry constraints upon services strategy adoption.

Our second contribution is in identifying that NSD outcomes appear to be a function of: service innovation strategy, processes, cultural, structural and people aspects. This observation suggests that overcoming NSD challenges may well involve studying all these themes together at a holistic level; this may help to identify and structure future understanding of the areas that researchers ought to consider when trying to understand the connection between NSD strategies and service innovation outcomes. In support of this suggestion we recommend drawing on the Pentathlon framework (Goffin \& Mitchell, 2005); and argue that in line with their work, managing service innovation in servitizing firms is likely to involve decisions and activities surrounding these interlocking areas that together contribute to innovation success. Taking this broad, integrative perspective on the elements of innovation management should enhance understanding of how manufacturers with different services strategies implement service transformation and overcome, or fail to overcome, key challenges as they attempt to transform.

Services innovation, in this context, is likely to involve NSD processes that are based on, and linked to, NPD processes. These processes run in parallel, with important touchpoints between the actors involved in both processes, which appear vital to the successful development of appropriate product and services offerings. This approach can generate 
some communications issues; however, it also means that despite the underlying change that servitization brings, in contrast to prior research, it appears that firms adopt a common development process for new services innovation that everybody in the organisation understands. This common understanding may then be an important factor in whether or not servitization initiatives are successful.

Managerial implications emerge with regards to the responses adopted to overcome key services innovation challenges, across four types of organisations with differing services innovation strategies. We suggest that manufacturers do not, and largely should not, 'break free' from their established product heritage, despite previous calls to do so (Kindström \& Kowalkowski, 2014). Instead, manufacturers with strong product advantages should attempt to create new services in parallel with, and in support of, their existing product expertise, but they should recognise that retaining and resourcing a very product-focused strategy may ultimately risk limiting their ability to successfully grow NSD activities. If disruptive innovation threatens to destroy their existing product market completely then a more radical shift to a complete service focus may be preferable.

Organisations attempting to build new business models face challenges around key capabilities; needing to support their services strategy incrementally, while attempting to deliver step changes in service value outcomes (Story, Raddats, Burton, Zolkiewski \& Baines, 2016). In response to these challenges, firms need to develop clear lines of communication between their NPD and NSD staff, to reduce conflict and increase learning across the organisation, and ensure that staff can understand each other's issues - through such options as training and job switches. Structures also need to be put in place to support 
clearer revenue attribution across SBUs and to help with the services personnel constraints that many servitizing firms face, which hinder services implementation efforts. Our findings suggest that multi-skilling current staff, building standardisation or modularisation of services, where possible, and developing supporting process tools improve firms' NSD outcomes.

The exploratory nature of the study presents limitations with regards to generalisability. We have attempted to purposefully identify cases representing manufacturers with particular strategic approaches identified on the Raddats \& Kowalkowski (2014) model, but future research could consider additional variables that might impact effectiveness at responding to various themes within NSD challenges, such as manufacturer size, technology focus of industry and degree to which a manufacturer's offering already involves a services component. Future research should also test the impact of the themes and challenges identified and the types of strategic responses adopted using a large sample of manufacturers. Another potential limitation relates to the industry heterogeneity of our cases. This needs further exploration but our approach has provided important insight into commonality of processes across very different firms and taking an integrative approach to the research can be seen to give interesting insight into common issues that face many manufacturers.

\section{References}

Aaboen, L., Dubois, A., Lind, F., 2012. Capturing processes in longitudinal multiple case studies. Industrial Marketing Management, 41: 235-246.

Baines, T. S., Lightfoot, H. W., Benedettini, O., Kay, J. M., 2009. The servitization of manufacturing: A review of literature and reflection on future challenges. Journal of Manufacturing Technology Management, 20(5): 547-567. 
Baines, T.S., Lightfoot, H., 2014. Servitization of the manufacturing firm: Exploring the operations practices and technologies that deliver advanced services. International Journal of Operations and Production Management, 34(1): 2-35.

Baveja, S.S., Gilbert, J., Ledingham, D., 2004. From products to services: why it's not so simple. Harvard Management Update, 9(4): 3-5.

Benedettini, O., Neely, A., Swink, M., 2015. Why do servitized firms fail? A risk-based explanation. International Journal of Operations and Production Management, 35(6): 946979.

Bettencourt, L.A., Brown, S.W., 2013. From goods to great: Service innovation in a productdominant firm. Business Horizons, 56(3):277-283.

Brax, S., 2005. A manufacturer becoming service provider-challenges and a paradox. Managing Service Quality: An International Journal, 15(2): 142-155.

Carlborg, P., Kindström, D., Kowalkowski, C., 2014. The evolution of service innovation research: a critical review and synthesis. The Service Industries Journal, 34(5): 373-398.

Cooper, R.G., 2008. The Stage-Gate ${ }^{\circledR}$ Idea-to-Launch Process - Update, What's New, and NexGen Systems. Journal of Product Innovation Management, 25: 213-232.

Cooper, R.G., Edgett, S J. 2012. Best practices in the idea to-launch process and its governance. Research-Technology Management, 55(2): 43-54.

Creswell, J.W., 2003. Research design: Qualitative, quantitative, and mixed methods approaches. Sage, Thousand Oaks.

Creswell, J.W., Miller, D.L., 2000. Determining Validity in Qualitative Inquiry, Theory into Practice 39(3): 124-130.

Dachs, B., Biege, S., Borowiecki, M., Lay, G., Jäger, A., Schartinger, D., 2014. Servitisation in European manufacturing industries: Empirical evidence from a large-scale database. The Service Industries Journal, Vol. 34 Iss. 1, pp. 5-23.

de Jong, J., Vermeulen, P., 2003. Organizing successful new service development: A literature review. Management Decision, 41: 844-858.

Dexter, L. A., 2012. Elite and Specialized Interviewing. ECPR Press, Colchester, UK.

Dubois, A., Gadde, L.-E., 2002. Systematic combining: An abductive approach to case research. Journal of Business Research, 55(7): 553-560.

Eggert, A., Hogreve, J., Ulaga, W., Muenkhoff, E., 2011. Industrial Services, Product Innovations, and Firm Profitability: A Multiple-Group Latent Growth Curve Analysis. Industrial Marketing Management, 40(5): 661-670.

Eggert, A., Thiesbrummel, C., Deutscher, C., 2015. Heading for new shores: Do service and hybrid innovations outperform product innovations in industrial companies? Industrial Marketing Management, 45: 173-183.

Eisenhardt, K.M., 1989. Building theories from case study research. Academy of Management Review, October 14(4): 532-550.

Ettlie, J.E., Rosenthal, S. R., 2011. Service versus Manufacturing Innovation. Journal of Product Innovation Management, 28(2): 285-299. 
Ettlie, J.E., Rosenthal, S.R., 2012. Service innovation in manufacturing. Journal of Service Management, 23(3):440-454.

Fang, E., Palmatier, R., Steenkamp, J., 2008. Effect of service transition strategies on firm value. Journal of Marketing, 72(4): 1-14.

Gallouj, F., Windrum, P., 2009. Services and services innovation. Journal of Evolutionary Economics, 19(2): 141-148.

Gebauer, H., 2008. Identifying service strategies in product manufacturing companies by exploring environment-strategy configurations. Industrial Marketing Management, 37(3): 278-291.

Gebauer, H., Edvardsson, B., Gustafsson, A., Witell, L., 2010. Match or mismatch: Strategystructure configurations in the service business of manufacturing companies. Journal of Service Research, 13(2): 198-215.

Gebauer, H., Paiola, M., Edvardsson, B., 2010. Service business development in small and medium capital goods manufacturing companies. Managing Service Quality: An International Journal, 20(2): 123-139.

Goffin, K., Mitchell, R., 2005. Innovation management: Strategy and implementation using the pentathlon framework (Vol. 2). Basingstoke: Palgrave Macmillan.

Gremyr, I., Löfberg, N., Witell, L., 2010. Service innovations in manufacturing firms. Managing Service Quality: An International Journal, 20(2): 161-175.

Gremyr, I., Witell, L., Löfberg, N., Edvardsson, B., Fundin, A., 2014. Understanding new service development and service innovation through innovation modes. Journal of Business and Industrial Marketing, 29(2): 123-131.

Hirschman, E.C., 1986. Humanistic inquiry in marketing research: Philosophy, method and criteria, Journal of Marketing Research, 23: 237-249.

Kindström, D., Kowalkowski, C., 2009. Development of industrial service offerings: A process framework. Journal of Service Management, 20(2): 156-172.

Kindström, D., Kowalkowski, C., 2014. Service innovation in product-centric firms: A multidimensional business model perspective. Journal of Business and Industrial Marketing 29(2): 96-111.

Kindström, D., Kowalkowski, C., Sandberg, E., 2013. Enabling service innovation: A dynamic capabilities approach. Journal of Business Research, 66(8): 1063-1073.

King, N., 2004. Using templates in the thematic analysis of texts. In Cassell, C., Symon, G. (Eds). Essential guide to qualitative methods in organisational research. California: Sage, Thousand Oaks, 256-270.

Kowalkowski, C., Kindström, D., Alejandro, T., Brege, S., Biggemann, S., 2012. Service infusion as agile incrementalism in action. Journal of Business Research, 65(6): 765-772.

Kowalkowski, C., Windahl, C., Kindström D., Gebauer, H., 2015. What service transition? Rethinking established assumptions about manufacturers' service led growth strategies. Industrial Marketing Management, 44(2): 59-69. 
Lightfoot, H. W., Gebauer, H., 2011. Exploring the alignment between service strategy and service innovation. Journal of Service Management, 22(5): 664-683.

Löfberg, N., Witell, L., Gustafsson, A., 2010. Service strategies in a supply chain. Journal of Service Management, 21(4): 427-440.

Mathieu, V., 2001a. Product Services: From a Service Supporting the Product to a Service Supporting the Client. Journal of Business and Industrial Marketing, 16(1): 39-61.

Mathieu, V., 2001b. Service strategies within the manufacturing sector: benefits, costs and partnership. International Journal of Service Industry Management, 12(5), 451-475.

Matthyssens, P., Vandenbempt, K., 2008. Moving from basic offerings to value-added solutions: strategies, barriers and alignment. Industrial Marketing Management, 37(3): 316-328.

Miles, M.B., Huberman, A.M., 1994. Qualitative Data Analysis (2nd Ed.). California: Sage, Newbury Park, 10-12.

Möller, K., Rajala, A., 2007. Rise of strategic nets - New modes of value creation. Industrial Marketing Management, 36: 895-908.

Neely, A., 2008. Exploring the financial consequences of the servitization of manufacturing. Operations Management Research, 1(2): 103-118.

Neu, W.A., Brown, S.W., 2005. Forming successful business-to-business services in goodsdominant firms. Journal of Service Research, 8(1): 3-17.

Nijssen, E. J., Hillebrand, B., Vermeulen, P. A., Kemp, R. G., 2006. Exploring product and service innovation similarities and differences. International Journal of Research in Marketing, 23(3): 241-251.

O'Reilly, C.A., Tushman, M.L., 2011. Organizational ambidexterity in action: How managers explore and exploit. California Management Review, 53(4): 5-22.

Öhman, M., Finne, M., Holmström, J., 2015. Measuring service outcomes for adaptive preventive maintenance. International Journal of Production Economics, 170(Part B):457467.

Oliva, R., Kallenberg, R., 2003. Managing the transition from products to services. International Journal of Service Industry Management, 14(2): 160-172.

Ostrom, A. L., Bitner, M. J., Brown, S. W., Burkhard, K. A., Goul, M., Smith-Daniels, V., Demirkan H., Rabinovich, E., 2010. Moving forward and making a difference: Research priorities for the science of service. Journal of Service Research, 13(1): 4-36.

Peillon, S., Pellegrin, C., Burlat, P., 2015. Exploring the servitization path: A conceptual framework and a case study from the capital goods industry. Production and Planning Control, 26(14-15): 1264-1277.

Rabetino, R., Kohtamäki, M., Lehtonen, H., Kostama, H., 2015. Developing the concept of life-cycle service offering. Industrial Marketing Management, 49: 53-66.

Raddats, C., Burton, J. and Ashman, R. 2015. Resource configurations for services success in manufacturing companies. Journal of Service Management, 26 (1): 97-116. 
Raddats, C., Kowalkowski, C., 2014. A reconceptualization of manufacturers service strategies. Journal of Business-to-Business Marketing, 21(1): 19-34.

Raja, J. Z., Bourne, D., Goffin, K., Çakkol, M., Martinez, V., 2013. Achieving Customer Satisfaction through Integrated Products and Services: An Exploratory Study. Journal of Product Innovation Management, 30(6): 1128-1144.

Santamaría, L., Jesús Nieto, M., Miles, I., 2012. Service innovation in manufacturing firms: Evidence from Spain. Technovation, 32(2): 144-155.

Silverman, D., Marvasti, A., 2008. Doing Qualitative Research- A comprehensive Guide. New Delhi: Sage Publications.

Story, V.M., Raddats, C., Burton, J., Zolkiewski, J. and Baines, T. 2016. Capabilities for advanced services: A multi-actor perspective. Industrial Marketing Management, http://dx.doi.org/10.1016/j.indmarman.2016.04.015.

Snyder, H., Witell, L., Gustafsson, A., Fombelle, P., Kristensson, P., 2016. Identifying categories of service innovation: A review and synthesis of the literature. Journal of Business Research, 69: $2401-2408$.

Suarez, F.F., Cusumano, M.A., Kahl, S., 2013. Services and the business models of product firms: An empirical analysis of the software industry. Management Science, 59(2): 420435.

Tukker, A., 2004. Eight Types of Product-Service System: Eight Ways to Sustainability? Experiences from Suspronet. Business Strategy and the Environment, 13(4): 246-260.

Turunen, T., Finne, M., 2014. The organisational environment's impact on the servitization of manufacturers. European Management Journal, 32(4): 603-615.

Ulaga, W., Reinartz, W. J., 2011. Hybrid offerings: how manufacturing firms combine goods and services successfully. Journal of Marketing, 75(6): 5-23.

Vandermerwe, S., Rada, J., 1989. Servitization of business: Adding value by adding services. European Management Journal, 6(4): 314-324.

Visnjic, I., Wiengarten, F., Neely, A., 2016. Only the Brave: Product Innovation, Service Business Model Innovation, and Their Impact on Performance. Journal of Product Innovation Management, 33(1): 36-52.

Wilson, E.J., Vlosky R.P., 1997. Partnering relationship activities: Building theory from case study research. Journal of Business Research, 39, 59 - 70.

Yin, Robert K., 2013. Case Study Research Design and Methods (Applied Social Research Methods) (Fifth Ed.). California: Sage, Thousand Oaks. 
Appendix: Challenges and Responses Relating to NSD Processes

\begin{tabular}{|c|c|c|c|c|}
\hline Themes & SecurCo & ChemCo & TelCo & AeroCo \\
\hline $\begin{array}{l}\text { Product } \\
\text { versus } \\
\text { service } \\
\text { innovation } \\
\text { mind-set }\end{array}$ & $\begin{array}{l}\text { "[services is] a big } \\
\text { growth initiative ...but } \\
\text { it is an enabler for } \\
\text { selling stuff in boxes... } \\
\text { we wouldn't get into } \\
\text { the game if we didn't". } \\
\text { "At the end of the day } \\
\text { we still make } \\
\text { hardware... we tend to } \\
\text { believe that we will still } \\
\text { serve our same } \\
\text { channels. Now, it also } \\
\text { means we are going to } \\
\text { develop apps, that will } \\
\text { primarily have different } \\
\text { routes to market into } \\
\text { other ecosystems that } \\
\text { are out there. So, yes, } \\
\text { we have to look } \\
\text { downstream into how } \\
\text { to sell software as it's } \\
\text { something that is not in } \\
\text { our DNA really." }\end{array}$ & $\begin{array}{l}\text { "The whole idea of our } \\
\text { service business, our service } \\
\text { offering, is to sell our } \\
\text { product." } \\
\text { "The biggest limitation is that } \\
\text { selling a complete service } \\
\text { requires a totally different set } \\
\text { of capabilities and here we } \\
\text { have a handful of people that } \\
\text { know what to do, ... but we } \\
\text { have no training culture. So } \\
\text { selling this more complex } \\
\text { thing requires particularly } \\
\text { trained sales people firstly, } \\
\text { but secondly also internal } \\
\text { people to understand the } \\
\text { new challenge with those } \\
\text { more complex service } \\
\text { offerings." }\end{array}$ & $\begin{array}{l}\text { "At the time there were 140-something } \\
\text { solutions... Over the two years, we've } \\
\text { transformed to reduce the teams } \\
\text { massively. We had four different } \\
\text { practice areas and now we're just } \\
\text { [systems team] and we have probably } \\
\text { no more than about } 20 \text { solutions.... } 95 \% \\
\text { to } 98 \% \text { tied to our products". }\end{array}$ & $\begin{array}{l}\text { "I think there is certainly a } \\
\text { senior level acceptance } \\
\text { that is the right thing to do } \\
\text { and that is gradually } \\
\text { maturing through those } \\
\text { other lines of business, but } \\
\text { it does take time". } \\
\text { "Our first call will always } \\
\text { be to use the company's } \\
\text { products but if these } \\
\text { products mean that we are } \\
\text { not going to win the } \\
\text { business then we have got } \\
\text { to look elsewhere." }\end{array}$ \\
\hline
\end{tabular}




\begin{tabular}{|c|c|c|c|c|}
\hline $\begin{array}{l}\text { NPD/NSD } \\
\text { processes }\end{array}$ & $\begin{array}{l}\text { "We try to avoid having } \\
\text { one-off small } \\
\text { developments because } \\
\text { (of) all the approvals... } \\
\text { we've got to be very } \\
\text { careful we don't get } \\
\text { blocked with lots of } \\
\text { small stuff". } \\
\text { "If you look at our R\&D } \\
\text { skills' pool, it's been } \\
\text { built up over 20-30 } \\
\text { years to deliver the kind } \\
\text { of software that we } \\
\text { would need in } \\
\text { proprietary } \\
\text { systems....when you } \\
\text { turn round and say to } \\
\text { somebody open } \\
\text { protocol, IP } \\
\text { environment' most of } \\
\text { our people can't do } \\
\text { that". }\end{array}$ & $\begin{array}{l}\text { "It's almost like 'bushman' } \\
\text { mentality ...an innovation, it } \\
\text { just kind of gets knocked and } \\
\text { kicked around the group... so } \\
\text { it's really not a process, it's } \\
\text { more a brainstorming } \\
\text { operation and l'd say that's } \\
\text { even the case at } \\
\text { management level. ... We do } \\
\text { napkin, fag packet type } \\
\text { calculations and if it seems to } \\
\text { make sense, then that's what } \\
\text { we do. We don't formally do } \\
\text { a market appraisal. If the } \\
\text { boss feels it's okay, then ok". }\end{array}$ & $\begin{array}{l}\text { "The very early [approval gates] are at } \\
\text { the [service SBU] level, then it usually } \\
\text { goes to the [next] level, and if there's a } \\
\text { major investment it probably goes right } \\
\text { up to the [group] leadership team to do } \\
\text { that, depending on the spend". } \\
\text { "The challenge is being able to address } \\
\text { each area in convincing ways, giving } \\
\text { them what they want and that means } \\
\text { the innovation for some is relatively } \\
\text { safe, it's much more productised } \\
\text { innovation, for others it's very much } \\
\text { bespoke. Hopefully in the middle we get } \\
\text { some customers where we can go and } \\
\text { try some things, prove it works and } \\
\text { then feed it back in later". } \\
\text { "We have certain customers we know ... } \\
\text { they know us and there's a good trust } \\
\text { relationship. We can then go and take } \\
\text { ideas along and develop them or } \\
\text { bounce ideas off them; develop proofs } \\
\text { of concept. There are other customers } \\
\text { that we definitely wouldn't go to with } \\
\text { something new". } \\
\text { "It gets picked up and fed back in and } \\
\text { 'what went wrong here; why didn't it } \\
\text { work; what have we missed; what have } \\
\text { we learnt for next time?". }\end{array}$ & $\begin{array}{l}\text { "It is tailorable in that you } \\
\text { have to go through each } \\
\text { gate but for a simple } \\
\text { solution ... we still have to } \\
\text { go through the gates but } \\
\text { the meeting may be a } \\
\text { couple of PowerPoint } \\
\text { slides and some chat... If } \\
\text { the solution is more } \\
\text { complex and the risks we } \\
\text { are taking more } \\
\text { complicated, then we } \\
\text { would be more careful } \\
\text { with the process". } \\
\text { The [manager] who starts } \\
\text { the relationship with the } \\
\text { customer...has tharte } \\
\text { blanche' to fix the } \\
\text { customer's problem. As it } \\
\text { comes closer to putting an } \\
\text { offeron the table then that } \\
\text { person needs help from } \\
\text { experts around the } \\
\text { company to gauge } \\
\text { whether the company can } \\
\text { deliver that solution and } \\
\text { whether we can make } \\
\text { money out of it. }\end{array}$ \\
\hline
\end{tabular}




\begin{tabular}{|c|c|c|c|c|}
\hline $\begin{array}{l}\text { Connections } \\
\text { between } \\
\text { NPD and } \\
\text { NSD }\end{array}$ & $\begin{array}{l}\text { "the systems business } \\
\text { integrate our devices to } \\
\text { the control panels and } \\
\text { all the peripherals into } \\
\text { a system and... will } \\
\text { maintain those devices } \\
\text { in the field. So, we } \\
\text { don't have an after- } \\
\text { market business, we } \\
\text { just have an OEM } \\
\text { business... we sell those } \\
\text { detectors to (service } \\
\text { SBU) group at the same } \\
\text { price....This is the } \\
\text { business model that we } \\
\text { have today. The largest } \\
\text { part of the service } \\
\text { model still continues at } \\
\text { the systems side; they } \\
\text { are the customer-facing } \\
\text { business." }\end{array}$ & $\begin{array}{l}\text { "the sales team is trying to } \\
\text { look at what we can do for } \\
\text { the customers and where we } \\
\text { can improve [product] } \\
\text { performance...then you bring } \\
\text { it back into the company and } \\
\text { start to discuss with } \\
\text { management... in general, } \\
\text { the sales forces are in the } \\
\text { most important position; they } \\
\text { are talking with the } \\
\text { customer, they see what } \\
\text { markets need". }\end{array}$ & $\begin{array}{l}\text { "For service-led [innovation], we've got } \\
\text { guys in the market... close to customers. } \\
\text { It's more of a consultative type of } \\
\text { selling... we look at what the customer's } \\
\text { 'pain points' are... try to foresee where } \\
\text { the industry's going; and try to ... create } \\
\text { something unique for the customer". }\end{array}$ & $\begin{array}{l}\text { "We do feed back into the } \\
\text { lines of business. For this } \\
\text { solution, this is the range } \\
\text { products we are going to } \\
\text { use and why we are not } \\
\text { using [AeroCo] products. } \\
\text { They [product people] can } \\
\text { take on-board what we } \\
\text { have told them. Or if they } \\
\text { want to ignore it because } \\
\text { they have other customers } \\
\text { that just want to buy } \\
\text { product then that's their } \\
\text { own call". }\end{array}$ \\
\hline $\begin{array}{l}\text { People and } \\
\text { Services } \\
\text { Deployment }\end{array}$ & $\begin{array}{l}\text { "It's a very heavy } \\
\text { person-type of activity } \\
\text { and we haven't got the } \\
\text { resources; so we } \\
\text { actually don't do a lot } \\
\text { of the ongoing annual } \\
\text { maintenance. That's a } \\
\text { very labour intensive } \\
\text { activity and really }\end{array}$ & $\begin{array}{l}\text { "Sometimes we do not have } \\
\text { really dedicated people doing } \\
\text { just one thing, or developing } \\
\text { just one thing ...and our labs } \\
\text { are also very much } \\
\text { production oriented. Our labs } \\
\text { are more related to } \\
\text { production so maybe we are } \\
\text { not so innovative with }\end{array}$ & $\begin{array}{l}\text { "Delivery pays the bills today. } \\
\text { Innovation pays the bills in the future. } \\
\text { So, we've got to pay the bills now and } \\
\text { try and come up with something new } \\
\text { that's going to pay the bills in the } \\
\text { future. So it's not ideal. } \\
\text { "There used to be a large consulting } \\
\text { team and they were very bright guys }\end{array}$ & $\begin{array}{l}\text { "Once the customer } \\
\text { appreciates he is on a fixed } \\
\text { price contract with KPIs, he } \\
\text { starts to open up knowing } \\
\text { that if you don't make a } \\
\text { profit and if sums were } \\
\text { horrendously wrong and } \\
\text { we are going to end up } \\
\text { making a loss, then at the }\end{array}$ \\
\hline
\end{tabular}


that's the preserve of what our customers do...(we) struggle with the services a little bit as well because we don't do it globally, ... and lack a bit of critical mass to really generate efficiencies".

absolutely new products, or and we've still got some of them, but a
we do it more on an ad hoc very small number, and I think it's to
basis. This has simply to do the detriment of the company".
with the size of the company. "Once they've won a service, they need
Sometimes we simply lack to deliver it against a standard model
manpower".
"We may, and have in the that can be done by sub-contractors, by
past, carried out service the local organisations, by the Remote
offering when we're not Delivery Centres (RDCs)...we're trying
supplying our product, to...re-industrialise and drive a lot more
usually just to keep our delivery through RDCs because you can
service team ticking over get economies of scale, you've got
when they have a lull in repeatability, you can drive
activity".
activity". end of the contract we are going to walk away and he then has a problem trying to find someone to replace [that] infrastructure. As the customers become more experienced they appreciate that and open up to us and we work together to put improvements in place that cut our costs".

"The way we incentivise our people, even with a new solution (will be higher risk because there is no history behind it), we believe that the continuous improvement ethos that we have will find further savings". 